\title{
Exercise-induced oxidative stress in older adults as a function of habitual activity level
}

Citation for published version (APA):

Meijer, E. P., Goris, A. H. C., van Dongen, J. L. J., Bast, A., \& Westerterp, K. R. (2002). Exercise-induced oxidative stress in older adults as a function of habitual activity level. Journal of the American Geriatrics Society, 50(2), 349-353. https://doi.org/10.1046/j.1532-5415.2002.50069.x

Document status and date:

Published: 01/01/2002

DOI:

10.1046/j.1532-5415.2002.50069.x

Document Version:

Publisher's PDF, also known as Version of record

Document license:

Taverne

Please check the document version of this publication:

- A submitted manuscript is the version of the article upon submission and before peer-review. There can be important differences between the submitted version and the official published version of record.

People interested in the research are advised to contact the author for the final version of the publication, or visit the DOI to the publisher's website.

- The final author version and the galley proof are versions of the publication after peer review.

- The final published version features the final layout of the paper including the volume, issue and page numbers.

Link to publication

\footnotetext{
General rights rights.

- You may freely distribute the URL identifying the publication in the public portal. please follow below link for the End User Agreement:

www.umlib.nl/taverne-license

Take down policy

If you believe that this document breaches copyright please contact us at:

repository@maastrichtuniversity.nl

providing details and we will investigate your claim.
}

Copyright and moral rights for the publications made accessible in the public portal are retained by the authors and/or other copyright owners and it is a condition of accessing publications that users recognise and abide by the legal requirements associated with these

- Users may download and print one copy of any publication from the public portal for the purpose of private study or research.

- You may not further distribute the material or use it for any profit-making activity or commercial gain

If the publication is distributed under the terms of Article $25 \mathrm{fa}$ of the Dutch Copyright Act, indicated by the "Taverne" license above, 


\title{
Exercise-Induced Oxidative Stress in Older Adults as a Function of Habitual Activity Level
}

\author{
Erwin P. Meijer, PhD, * Annelies H. C. Goris, PhD, * Joost L. J. van Dongen, $\neq$ Aalt Bast, PhD, ${ }^{\dagger}$ \\ and Klaas R. Westerterp, PhD*
}

OBJECTIVES: It has been suggested that regular physical activity might maintain and promote the antioxidant defense capacity against oxidative stress. Therefore, we assessed exercise-induced oxidative stress in relation to habitual physical activity level (PAL) in older adults.

DESIGN: The study included a 2-week observation period for the measurement of average daily metabolic rate (ADMR) and PAL. Exercise-induced oxidative stress was measured during a 45 -minute cycling test at submaximal intensity.

SETTING: A university medical research center.

PARTICIPANTS: Twenty-six subjects volunteered for the study $(\mathrm{n}=26$; mean age \pm standard deviation $60 \pm 1$; body mass index $27 \pm 1 \mathrm{~kg} / \mathrm{m}^{2}$ ).

MEASUREMENTS: PAL was determined as ADMR combined with a measurement of basal metabolic rate (BMR): $\mathrm{PAL}=\mathrm{ADMR} / \mathrm{BMR}$. ADMR was measured over 2 weeks with the doubly labeled water method, preceded by a BMR measurement with a ventilated hood. Antipyrine oxidation was used as marker for oxidative stress in vivo. Reaction of antipyrine with hydroxyl radicals results in the formation of para-hydroxyantipyrine $(\mathrm{p}-\mathrm{APOH})$ and ortho-hydroxyantipyrine (o-APOH), where $\mathrm{o}-\mathrm{APOH}$ is not formed through alternative oxygenetic pathways.

RESULTS: PAL was inversely related to the exercise-induced increase in the ratio of o-APOH to native antipyrine $(r=$ $-0.49, P=.010)$. The relationship between PAL and exercise-induced increase in the ratio of $\mathrm{p}-\mathrm{APOH}(r=-0.30$, $P=.140)$ or thiobarbituric acid reactive species $(r=$ $-0.31, P=.130)$ did not reach the level of significance.

CONCLUSION: Physically active older adults have a reduced exercise-induced oxidative stress than older adults with a lower level of physical activity. It seems that regular

From the "Departments of Human Biology and +Pharmacology and Toxicology, Maastricht University, Maastricht, The Netherlands; and $\ddagger^{\ddagger}$ Laboratory for Macromolecular and Organic Chemistry, Eindhoven University of Technology, Eindhoven, The Netherlands.

Address correspondence to Klaas R. Westerterp, PhD, Department of Human Biology, Maastricht University, P.O. Box 616, 6200 MD

Maastricht, The Netherlands. E-mail: k.westerterp@hb.unimaas.nl physical activity improves the antioxidant defense capacity. J Am Geriatr Soc 50:349-353, 2002.

Key words: physical activity; antipyrine; doubly labeled water; free radicals

A ging is associated with a decline in physical activity. Regular physical activity and exercise are recommended for maintenance of optimal health and prevention or management of chronic diseases. ${ }^{1}$ It has been shown that low levels of physical fitness are associated with an increased risk of cardiovascular disease mortality.2,3 Alternatively, there is increasing evidence indicating that exercise, especially when performed strenuously, is associated with increased production of reactive oxygen species (ROS).4,5 ROS may increase during exercise as a result of a higher mitochondrial oxygen $\left(\mathrm{O}_{2}\right)$ consumption and electron transport flux. ${ }^{6}$ A state of increased levels of intracellular ROS production is referred to as oxidative stress. It has been shown that aging is associated with an increased susceptibility to oxidative stress. ${ }^{7}$ However, the relationship between oxidative stress and physical activity is still poorly understood, particularly in advanced age, because there is a substantial lack of data regarding the effects of exercise and training on oxidative stress in older people. ${ }^{8}$

One of the reasons for the lack of data is the methodological aspect concerning the assessment of oxidative stress and the habitual activity level. In this study, we used antipyrine oxidation (2,3-Dimethyl-1-phenyl-3-pyrazolin-5-one) as a marker for measuring oxidative stress. The properties of antipyrine make it a suitable marker for assessing oxidative stress in vivo. After oral ingestion, antipyrine is completely absorbed and uniformly distributed in the total body water after approximately 1 hour. ${ }^{9}$ Additionally, antipyrine is independent of blood flow to the liver, which is an advantage in clinical studies where blood flow is altered (e.g. during exercise experiments). ${ }^{10}$ Moreover, the reaction rate constant of antipyrine with hydroxyl radicals is approximately $10^{10} \mathrm{~L} \cdot \mathrm{mol}^{-1} \mathrm{~s}^{-1} \cdot{ }^{11}$ Exposure of an antipyrine solution in water to ${ }^{60} \mathrm{cobalt}\left({ }^{60} \mathrm{Co}\right) \gamma$-radiation leads to the formation 
of three phenolic antipyrine derivatives: para-hydroxyantipyrine (p-APOH), ortho-hydroxyantipyrine $(\mathrm{o}-\mathrm{APOH})$, and meta-hydroxyantipyrine. The latter two metabolites are not formed in man through the mono-oxygenase pathway of cytochrome P450 but through reaction with hydroxyl radicals. ${ }^{12}$ When an antioxidant is added to antipyrine solution in water, the conversion of antipyrine after ${ }^{60} \mathrm{Co} \gamma$-radiation can be used as indicator for free radical scavenging capacity of potential antioxidants. ${ }^{13} \mathrm{~A}$ recently performed study in patients with intermittent claudication, which is characterized by repetitive ischemia-reperfusion during physical exercise, showed that 5 -minutes walking exercise significantly increased the plasma concentration of hydroxylated antipyrine. ${ }^{14}$ Additionally, we showed that, in older adults, exercise resulted in a significant increase in the plasma levels of $\mathrm{p}-\mathrm{APOH}$ and o-APOH, to the same extent as in patients with intermittent claudication. ${ }^{15}$ Interestingly, no significant increase was observed in these levels in a group of young adults (aged $23 \pm 1$ ) who exercised at the same relative intensity. ${ }^{13}$ Consequently, the ratio of hydroxylated to unhydroxylated antipyrine is proposed as a measure of oxidative stress in vivo.

To assess physical activity level in an older population we used the doubly labeled water method. This method is generally held to be the criterion standard for assessing physical activity. ${ }^{16}$ The doubly labeled water method allows accurate measurement of average daily metabolic rate (ADMR) under unrestricted conditions over 1- to 3-week intervals, the optimal observation interval for the biological half-lives of the isotopes ${ }^{2}$ hydrogen $\left({ }^{2} \mathrm{H}\right)$ and ${ }^{18} \mathrm{O}$. In combination with a measurement of basal metabolic rate (BMR), the physical activity level (PAL) can be obtained $(\mathrm{PAL}=\mathrm{ADMR} / \mathrm{BMR})$. Thus, PAL is defined as the factor by which ADMR exceeds BMR.

So far, the potential role of oxidative stress during physical activity in old age remains unknown. Therefore, the purpose of this study was to examine the possible relationship between physical activity level and exercise-induced increase in oxidative stress in older adults. However, because of the high costs of using the doubly labeled water method, only older adults were included in the study.

\section{MATERIALS AND METHODS}

\section{Study Design}

The study included a 2-week observation period for the measurement of ADMR and PAL. Exercise-induced oxidative stress was measured during a 45 -minute cycling test at submaximal intensity by using free radical reaction products of antipyrine.

\section{Subjects}

Twenty-six healthy people aged 55 and older, with no known medical illness, receiving no prescription medication, and not using antioxidant vitamin supplements, participated in the study. To ensure that the measured PAL would reflect the actual PAL of a general older population, subjects were recruited from advertisements in the local media. Subject characteristics are shown in Table 1. Detailed information concerning the purpose and methods used in the study was provided before informed consent was obtained. The local Ethical Committee approved the study.

\begin{tabular}{|c|c|c|}
\hline Characteristic & $\begin{array}{c}\text { Mean } \pm \\
\text { Standard Error }\end{array}$ & Range \\
\hline Women/men & $13 / 13$ & - \\
\hline Age, years & $60 \pm 1$ & $55-65$ \\
\hline Body mass, kg & $75.5 \pm 2.2$ & $56-95$ \\
\hline Body mass index, $\mathrm{kg} / \mathrm{m}^{2}$ & $27 \pm 1$ & $21-43$ \\
\hline Body fat, \% & $34 \pm 1$ & $17-44$ \\
\hline Maximal oxygen uptake, L/minute & $1.84 \pm 0.12$ & $1.02-2.34$ \\
\hline Maximal workload capacity, watts & $145 \pm 49$ & $85-220$ \\
\hline
\end{tabular}

Note: Percentage of body fat was determined by underwater weighing combined with deuterium dilution.

\section{Energy Expenditure}

ADMR was measured with the doubly labeled water method according to the Maastricht protocol. ${ }^{17}$ Briefly, on the evening of Day 0 (10:00-11:00 p.m.), after a background urine sample was collected, subjects were given a weighed dose of a mixture of 99.9 atom $\%{ }^{2} \mathrm{H}_{2} \mathrm{O}$ in 10.0 atom $\% \mathrm{H}_{2}{ }^{18} \mathrm{O}$, such that baseline levels were increased to $300 \mathrm{ppm}$ or more for ${ }^{2} \mathrm{H}$ and $2300 \mathrm{ppm}$ or more for ${ }^{18} \mathrm{O}$. Additionally, urine samples were collected on the evening of Day 1 (from second void), the evening of Day 7, the morning of Day 8 (from second void), the evening of Day 14, and the morning of Day 15 (from second void). Isotope abundance was measured in urine by using an isotope-ratio mass spectrometer (Optima, Micromass, Manchester, UK). Carbon dioxide $\left(\mathrm{CO}_{2}\right)$ production was calculated from the isotope disappearance rate from the samples collected on Day 1,8 , and $15 . \mathrm{CO}_{2}$ production was converted to ADMR with a respiratory exchange ratio equal to the food quotient that was derived from a 1-week food diary. Mean PAL was calculated as ADMR/BMR.

\section{Basal Metabolic Rate}

BMR was measured at 6:45 a.m. after an overnight fast. After a period of 15 minutes under thermoneutral temperature conditions, $\mathrm{BMR}$ was measured for at least $15 \mathrm{~min}$ utes. $\mathrm{O}_{2}$ consumption and $\mathrm{CO}_{2}$ production were measured by means of a computerized, open-circuit, ventilated hood system. Gas analyses were performed using a paramagnetic $\mathrm{O}_{2}$ analyzer (Servomex Type 500A, Crowborough Sussex, UK) and an infrared $\mathrm{CO}_{2}$ analyzer (Servomex Type 12-X1). The system was similar to the analysis system for the respiration chambers described before. ${ }^{18}$ Calculation of BMR was based upon the Weir formula. ${ }^{19}$

\section{Exercise-Induced Oxidative Stress}

Maximal workload capacity (Wmax) and maximal $\mathrm{O}_{2}$ uptake $\left(\mathrm{VO}_{2} \max \right)$ were measured after the BMR measurement. Subjects exercised incrementally on an electronically braked cycle ergometer (Lode Excalibur, Groningen, The Netherlands) until volitional fatigue, as described before. ${ }^{20}$ One hour thereafter, a Teflon catheter (Quick Cath®II, Baxter Healthcare S.A., Swinford, Ireland) was placed into an antecubital vein, and a resting blood sample $(10 \mathrm{ml})$ was drawn. Immediately thereafter, subjects orally ingested $10 \mathrm{mg}$ antipyrine (Janssen Chimica, Geel, Belgium) per kilogram of body mass. One hour after ingestion, sub- 
jects cycled for 45 minutes at $50 \%$ Wmax (determined during the first cycling trial). Blood samples were drawn before and immediately after exercise. Blood was collected into ethylenediaminetetraacetic acid- $(1.34 \mathrm{mM})$ and glutathione $(0.65 \mathrm{mM})$-containing tubes and was centrifuged immediately $\left(3,000 \mathrm{rpm}, 10\right.$ minutes at $\left.4^{\circ} \mathrm{C}\right)$. Aliquots of plasma were frozen in liquid nitrogen and stored at $-20^{\circ} \mathrm{C}$ until further analysis.

\section{Markers of Oxidative Stress}

Antipyrine and thiobarbituric acid-reactive substances (TBARS) were used as indicators of oxidative stress. Antipyrine and its hydroxylated products were measured by reversed-phase high-performance liquid chromatography (HPLC) combined with mass spectrometry (HPLC-MS), as described before. ${ }^{21}$ Briefly, a reversed-phase Supersphere RP18 Endcapped column (LC-Packings, Amsterdam, The Netherlands), $150 \times 1 \mathrm{~mm}$ I.D., $d_{P}=4 \mu \mathrm{m}$ was attached to a liquid chromatography (LC) system consisting of a LC-10AT pump (Shimadzu Ltd., Kyoto, Japan), and a Triathlon autosampler (Spark Holland, Emmen, The Netherlands). The HPLC was connected to an API-300 LC/MS/ MS (Perkin Elmer Sciex Instruments, Thornhill, Canada), which operated in the multiple reaction mode with Turbo ionspray as interface. Sample pretreatment consisted of C18 solid-phase extraction (Sep-Pak® C18 Cartridges, Waters, Milford, MA) to wash out salts and proteins. Cartridges were conditioned with methanol and water. After that $450 \mu \mathrm{l}$ plasma was inserted in the cartridge, followed by $2 \mathrm{ml} \mathrm{am}$ monium-acetate buffer $(10 \mathrm{mM} ; \mathrm{pH}=5)$. The cartridge was flushed with $1.5 \mathrm{ml}$ methanol to elute the target components. Samples were evaporated to dryness under nitrogen pressure and dissolved with $450 \mu \mathrm{l}$ water, after which they stayed 30 minutes in an ultrasonic waterbath $\left(30^{\circ} \mathrm{C}\right)$. Afterwards, samples were filtered by using Spartan 13/20 filters (Schleicher \& Schuell, Dassel, Germany).

Because a competitive effect exists between antipyrine and other biomolecules for reaction with hydroxyl radicals, the formation of antipyrine hydroxylates is dependent on the available concentration of antipyrine. Therefore, ratios of phenolic derivatives to native antipyrine are used, similar to the salicylic acid method. ${ }^{22}$

TBARS were measured in plasma using a fluorescent thiobarbituric acid (TBA) assay. TBA (Sigma-Aldrich Chemie BV, Zwijndrecht, The Netherlands) $0.375 \mathrm{~g}$ was dissolved in $250 \mathrm{ml}$ demineralized water and $2.5 \mathrm{ml} 1 \mathrm{~mol} / \mathrm{L}$ hydrochloric acid; $111 \mu \mathrm{l}$ plasma and 1,000 $\mu \mathrm{l}$ TBA solution were mixed and vortexed in an Eppendorf cup, which was placed in a waterbath $\left(95^{\circ} \mathrm{C}\right)$ for 1 hour. Samples were cooled to room temperature, and the absorption was measured spectrophotometrically at $532 \mathrm{~nm}$ (Spectronic 1001, Meyvis, Bergen op Zoom, The Netherlands). Results were expressed as micromoles of malondialdehyde (MDA).

Additionally, plasma was analyzed for the concentrations of $\alpha$-tocopherol and triglycerides. Plasma $\alpha$-tocopherol content was analyzed by HPLC on an Inertsil ODS-2, C18 reversed-phase column (GL Sciences Inc., Tokyo, Japan). The plasma triglyceride concentration was determined enzymatically (glycerol phosphate oxidase Trinder method; Sigma Diagnostics, St. Louis, MO) with a COBAS FARA semiautomatic analyzer (Hoffman-La Roche, Basel, Switzerland).

\section{Statistical Analysis}

Data are presented as means \pm standard error. Paired $t$ tests (two-tailed) were used to evaluate differences between pre- and postexercise conditions. Simple regression was used to examine the relationship between PAL and the indicators of oxidative stress. Correlations are Pearson product-moment correlations. Statistical significance was accepted as $P<.05$. The StatView5.0 program (SAS Institute Inc., Cary, NC) was used as the statistical package.

\section{RESULTS}

Exercise significantly increased the ratio of $\mathrm{p}-\mathrm{APOH}$ to native antipyrine from $9.1 \times 10^{-3} \pm 0.9 \times 10^{-3}$ preexercise to $11.8 \times 10^{-3} \pm 0.9 \times 10^{-3}$ postexercise $(P<.001)$. Additionally, the ratio of $\mathrm{o}-\mathrm{APOH}$ to native antipyrine increased from $7.7 \times 10^{-3} \pm 0.9 \times 10^{-3}$ preexercise to $11.9 \times$ $10^{-3} \pm 0.9 \times 10^{-3}$ postexercise $(P<.001)$, whereas the plasma level of TBARS increased from $0.36 \pm 0.02 \mu \mathrm{M}$ preexercise to $0.43 \pm 0.02 \mu \mathrm{M}$ postexercise $(P<.001)$, respectively. The mean PAL was $1.64 \pm 0.13$ (range 1.442.00). PAL was inversely related to the exercise-induced increase in the ratio of o-APOH to native antipyrine $(r=$ $-0.49, P=.010$ ) (Figure 1A). The relationship between PAL and the exercise-induced increase in the ratio of $\mathrm{p}-\mathrm{APOH}$ to native antipyrine (Figure $1 \mathrm{~B}$ ) and between PAL and the exercise-induced increase in the plasma level of TBARS (Figure 1C) did not reach the level of significance $(r=-0.30, P=.140$ and $r=-0.31, P=.130$, respectively). Additionally, adjusting the increase of TBARS for the plasma concentration of triglycerides did not improved the observed correlation $(r=-0.31, P=.128)$, whereas the increase in o-APOH after exercise remained significantly related to PAL after adjusting for the plasma $\alpha$-tocopherol concentration, $(r=-0.42, P<.05)$.

\section{DISCUSSION}

To our knowledge, this is the first study that examined the association of the daily PAL, as measured by the doubly labeled water method, on exercise-induced oxidative stress in older adults. The results of the study suggest that the exercise-induced oxidative stress, as measured by free radical reaction products of antipyrine, is reduced in physically active older adults compared with inactive older adults, when exercising at the same relative intensity.

It has been suggested that regular physical activity might maintain and promote the antioxidant defense capacity against oxidative stress. ${ }^{5}$ However, physical activity in free-living conditions is difficult to measure. Until now only one study had attempted to examine the relationship between PAL and the antioxidant defense mechanism in older people. Kostka et al. ${ }^{23}$ showed in older men (aged 65-84) that there was no association between PAL and resting TBARS values, plasma total antioxidant status, and levels of red blood cell antioxidants. PAL was measured using an activity questionnaire. Most activity questionnaires have not been validated against the criterion standard for the assessment of physical activity, the doubly labeled water method. ${ }^{24}$ In the present study, we used the doubly labeled water technique combined with a measurement of BMR to assess PAL in an older population. The measured PAL $(1.64 \pm 0.13)$ of the older subjects in the present study ranged from 1.44 to 2.0 . In the general 

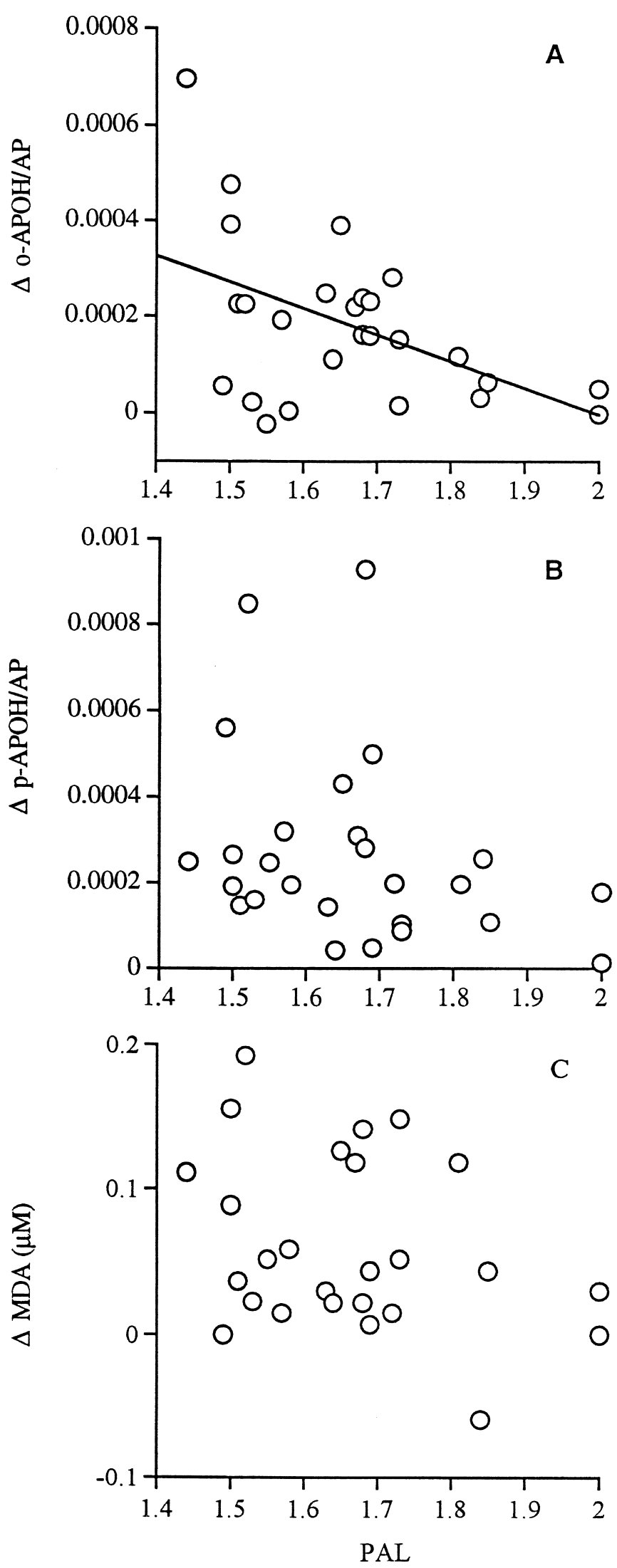

Figure 1. Relationship between physical activity level (PAL = average daily metabolic rate/basal metabolic rate) and indicators for exercise-induced oxidative stress. (A) PAL and the ratio of ortho-hydroxyantipyrine $(\mathrm{o}-\mathrm{APOH})$ to native antipyrine. $\mathrm{Y}=$ population, PAL ranges from 1.2 to 2.2. PAL is about 1.5 and 2.1 for sedentary and very active people, respectively. ${ }^{25}$ Therefore, one might assume that the measured PAL reflects the actual PAL of an older population.

The current study showed that the exercise-induced increase in the ratio of $\mathrm{O}-\mathrm{APOH}$ to antipyrine was significantly lower in physically active older adults than in inactive older adults $(r=-0.49, P=.010)$. In addition, after adjusting for the plasma $\alpha$-tocopherol concentration, the increase in $\mathrm{o}-\mathrm{APOH}$ after exercise remained significantly related to PAL $(r=-0.42, P<.05)$. O-APOH is not known to be formed in man through the mono-oxygenase pathway of cytochrome P450; it is only known as a free radical reaction product of antipyrine. ${ }^{12}$ The relationship between PAL and the exercise-induced increase in the ratio of $\mathrm{p}$-APOH to antipyrine failed to reach significance $(r=$ $-0.30, P=.140)$, which might be explained by the fact that $\mathrm{p}$-APOH can also be formed by natural breakdown of antipyrine by hepatic cytochrome P450 enzymes. ${ }^{10,26}$ In addition, the relationship between PAL and the plasma level of TBARS did not reach the level of significance $(r=$ $-0.31, P=.130$; Figure $1 \mathrm{C})$. The nonsignificant results might be due to the low statistical power of this study, because only a small number of subjects $(n=26)$ were studied. Furthermore, the thiobarbituric acid assay used to measure MDA lacks specificity when applied to human plasma. ${ }^{27}$ The results suggest that physically active older adults might have an improved intracellular antioxidant defense mechanism.

Recently, Brochu et al. ${ }^{25}$ observed that there was a strong positive association between physical fitness $\left(\mathrm{VO}_{2} \mathrm{max}\right)$ and physical activity-associated energy expenditure, as measured by the doubly labeled water method. Here, it was suggested that physically active older subjects had a higher physical fitness level than their physically less-active counterparts. In relation to the antioxidant defense system, Jenkins et al. ${ }^{28}$ reported in 12 younger adults (aged 17-19) that the superoxide dismutase activity in skeletal muscle was significantly related to the physical fitness level $(r=$ $0.70, P<.05)$. Furthermore, Shern-Brewer et al. ${ }^{29}$ showed a lower in vitro oxidizability of isolated low-density lipoprotein in physically active young adults than in sedentary young adults. Although it is difficult to compare the results of these studies with our findings, because they used only moderately to highly trained young adults, it seems that physical activity improves the antioxidant defense capacity in physically active older adults. In addition, several animal studies have observed that training can promote gene expression of muscle antioxidant enzymes, such as superoxide dismutase and glutathione peroxidase. ${ }^{30,31}$ However, in man, we recently observed that a 12 -week exercise training program had no effect on the exercise-induced increase in oxidative stress in older adults. ${ }^{15}$ In this study, 20 older people (aged $60 \pm 1$ ) participated in an ex-

$0.001-0.001 \mathrm{X} ; r=-0.49, P=.01$. (B) PAL and the ratio of para-hydroxyantipyrine ( $\mathrm{p}-\mathrm{APOH})$ to native antipyrine (AP). (C) PAL and the plasma level of thiobarbituric acid-reactive substances (TBARS). 
ercise training group, with 13 people (aged $64 \pm 2$ ) in a control group, and they performed the same cycling test as used in the present study. Although training significantly improved physical fitness, no significant differences were observed after 12 weeks of training in the exercise-induced increase in TBARS and free radical reaction products of antipyrine. ${ }^{15}$ In addition, PAL was not changed after 12 weeks training. However, in older adults, participation in an exercise training program results in a compensatory decline in the nontraining physical activity level, which might explain the fact that no changes in exercise-induced oxidative stress were observed. ${ }^{20}$ It could also be argued that a longer training period is necessary before any significant changes in oxidative stress during exercise would occur. Therefore a clearer differentiation might be seen when a group of sedentary and highly trained older adults are compared. Thus, we cannot conclude with certainty that regular exercise training is not an important determinant of oxidative stress.

The results of the present study seem to indicate that the recent level of physical activity could be an important factor mediating exercise-induced oxidative stress. It could be argued that regular physical activity results in an upregulation of the antioxidant defense system. However, no muscle biopsies were taken in the present study to measure gene expression of antioxidant enzymes such as superoxide dismutases or glutathione. In addition, it is known from animal studies that exercise moves mitochondrial respiration towards state 3 and may therefore protect against ROS production that mainly occurs during state $4 .{ }^{32}$ It could be speculated that regular exercise has the same effect in older humans, which raises the question of whether remaining or becoming physically active contributes more to lowered oxidative stress during exercise. Therefore, we can only speculate that, in older adults, an active lifestyle is likely a more important factor in improving the antioxidant defense mechanism than following an exercise training program. However, further studies are needed on this topic.

In conclusion, the present study showed that the exercise-induced increase in oxidative stress during exercise is lower in physically active older human subjects than in inactive older human subjects. Thus it seems that regular physical activity improves the antioxidant defense capacity.

\section{ACKNOWLEDGMENTS}

The authors would like to thank Loek Wouters for carrying out the doubly labeled water analysis.

\section{REFERENCES}

1. Booth FW, Gordon SE, Carlson CJ et al. Waging war on modern chronic disease: Primary prevention through exercise biology. J Appl Physiol 2000;88: 774-787.

2. Blair SN, Kohl III HW, Barlow CE et al. Changes in physical fitness and allcause mortality: A prospective study of healthy and unhealthy men. JAMA 1995;273:1093-1098

3. Erikssen G, Liestøl K, Bjørnholt J et al. Changes in physical fitness and changes in mortality. Lancet 1998;352:759-762.
4. Ji LL, Leeuwenburgh C, Leichtweis S et al. Oxidative stress and aging. Role of exercise and its influences on antioxidant systems. Ann NY Acad Sci 1998; $854: 102-117$

5. Sen CK. Oxidants and antioxidants in exercise. J Appl Physiol 1995;79:675-686.

6. Ji LL. Antioxidants and oxidative stress in exercise. Proc Soc Exp Biol Med 1999;222:283-292.

7. Mecocci P, Fano G, Fulle $S$ et al. Age-dependent increases in oxidative damage to DNA, lipids, and proteins in human skeletal muscle. Free Radic Biol Med 1999;26:303-308.

8. Polidori MC, Mecocci P, Cherubini A et al. Physical activity and oxidative stress during aging. Int J Sports Med 2000;21:154-157.

9. Siri WE. The gross composition of the body. Adv Biol Med Physiol 1956;4: 239-280.

10. Hartleb M. Drugs and the liver. Part II. The role of the antipyrine test in drug metabolism studies. Biopharm Drug Dispos 1991;12:559-570.

11. Forni LG, Mora-Arellano VO, Packer JE et al. Aminopyrine and antipyrine free radical-cations: Pulse radiolysis studies of one-electron transfer reactions. J Chem Soc Perkin Trans II 1988:1579-1584.

12. Coolen SAJ, Everaerts FM, Huf FA. Characterization of ${ }^{60} \mathrm{Co} \gamma$-radiation induced radical products of antipyrine by means of high-performance liquid chromatography, mass spectrometry, capillary zone electrophoresis, micellar electrokinetic capillary chromatography and nuclear magnetic resonance spectrometry. J Chromatogr A 1997;788:95-103.

13. Coolen SAJ. Antipyrine Hydroxylates As Indicators for Oxidative Damage. PhD thesis. Eindhoven: Eindhoven University of Technology, 2000.

14. Wijnen MHWA, Coolen SAJ, Vader HL et al. Antioxidants reduce oxidative stress in claudicants. J Surg Res 2001;96:183-187.

15. Meijer EP, Coolen SAJ, Bast A et al. Exercise training and oxidative stress in the elderly as measured by antipyrine hydroxylation products. Free Radic Res 2001;35:435-443.

16. Schoeller DA. Recent advances from application of doubly labeled water to measurement of human energy expenditure. J Nutr 1999;129:1765-1768.

17. Westerterp KR, Wouters L, van Marken Lichtenbelt WD. The Maastricht protocol for the measurement of body composition and energy expenditure with labeled water. Obes Res 1995;1:49-57.

18. Schoffelen PF, Westerterp KR, Saris WHM et al. A dual-respiration chamber system with automated calibration. J Appl Physiol 1997;83:2064-2072.

19. Weir JB. New methods for calculating metabolic rate with special reference to protein metabolism. J Physiol 1949;109:1-9.

20. Meijer EP, Westerterp KR, Verstappen FTJ. Effect of exercise training on total daily physical activity in elderly humans. Eur J Appl Physiol 1999;80:16-21.

21. Coolen SAJ, Van Lieshout M, Reijenga JC et al. Determination of phenolic derivatives of antipyrine in plasma with HPLC-Tandem MS using ESI and Turbo ionspray as interfaces. J Microcolumn Sep 1999;11:701-707.

22. McCabe DR, Maher TJ, Acworth IA. Improved method for the estimation of hydroxyl free radical levels in vivo based on liquid chromatography with electrochemical detection. J Chromatogr B 1997;691:23-32.

23. Kostka T, Drai J, Betrhouze SE et al. Physical activity, aerobic capacity and selected markers of oxidative stress and the anti-oxidant defence system in healthy active elderly men. Clin Physiol 2000;20:185-190.

24. Philippaerts RM, Westerterp KR, Lefevre J. Doubly labelled water validation of three physical activity questionnaires. Int J Sports Med 1999;20:284-289.

25. Brochu M, Starling RD, Ades PA et al. Are aerobically fit older individuals more physically active in their free-living time? A doubly labeled water approach. J Clin Endocrinol Metab 1999;84:3872-3876.

26. Danhof M, van Zuilen A, Boeijings JK et al. Studies of the different metabolic pathways of antipyrine in man. Oral versus i.v. administration and the influence of urinary collection time. Eur J Clin Pharmacol 1982;21:433-441.

27. Hageman JJ, Bast A, Vermeulen NP. Monitoring of oxidative free radical damage in vivo: Analytical aspects. Chem Biol Interact 1992;82:243-293.

28. Jenkins RR, Friedland R, Howald H. The relationship of oxygen uptake to superoxide dismutase and catalase activity in human skeletal muscle. Int J Sports Med 1984;5:11-14.

29. Shern-Brewer R, Santanam N, Wetzstein C et al. Exercise and cardiovascular disease: A new perspective. Arterioscler Thromb Vasc Biol 1998;18:1181-1187.

30. Gore M, Fiebig R, Hollander J et al. Endurance training alters antioxidant enzyme gene expression in rat skeletal muscle. Can J Physiol Pharmacol 1998;76:1139-1145.

31. Oh-ishi S, Toshinai K, Kizaki T et al. Effects of aging and/or training on antioxidant enzyme system in diaphragm of mice. Respir Physiol 1996;105:195-202.

32. Ramsey JJ, Harper M-E, Weindruch R. Restriction of energy intake, energy expenditure, and aging. Free Radic Biol Med 2000;29:946-968. 